\title{
A ARQUITETURA E A CIDADE NO JOGO FOTOGRÁFICO
}

\section{ARCHITECTURE AND THE CITY IN THE PHOTOGRAPHIC GAME}

\author{
Recebido em 29/9/2017 e aprovado em 30/11/2018
}

César Bastos de Mattos Vieira

Resumo: Se, inicialmente, a fotografia tirou proveito da arquitetura e da cidade, como modelos para provar a capacidade do aparato tecnológico de ser capaz de registrar de forma direta uma determinada cena, depois, tornou-se uma das principais ferramentas de apresentação e apreensão, no campo da arquitetura e do urbanismo. Entretanto, de certo modo, parece não serem estudadas as consequências das demandas fundamentais da fotografia - distância, luz e ordenamento - e os programas inseridos dentro do equipamento na alteração e/ou limitação do registro fotográfico. Este trabalho busca problematizar de que maneira este "jogo fotográfico" altera e, porque não especular?, direciona no sentido da construção de um imaginário limitado da "realidade" de edificações e cidades, onde o que não é passível de ser fotografado não existe.

Palavras-chaves: Arquitetura e Cidade. Fotografia. Imaginário.

Abstract: If in the early days photography took advantage of the architecture of cities as a model to demonstrate the capacity of technological apparatus in faithfully registering a particular scene, it later became one of the main instruments for presentation and learning in the field of architecture and urbanism. However, in a certain way, it seems that no studies have been made of the consequences resulting from the fundamental demands of photography - distance, light and the effect of order - and the programmes installed within the equipment of alteration and/or limitation of the photographic register. This study aims to raise questions on how this "photographic game" alters and, why not speculate? - guides, in terms of the construction of an imaginary limitation of "reality" in the buildings and cities where what is not possible to photograph does not exist.

Keywords: Architecture and City. Photography. Imaginary.

\footnotetext{
- Professor Adjunto, DE, da Faculdade de Arquitetura - UFRGS - Universidade Federal do Rio Grande do Sul, e professor colaborador do PROPUR - Programa de Pós-Graduação em Planejamento Urbano e Regional da UFRGS - Universidade Federal do Rio Grande do Sul.
} 
VIEIRA, César Bastos de Mattos. A arquitetura e a cidade no jogo fotográfico. Domínios da Imagem, Londrina, v. 12, n. 23, p. 32-50, jul./dez. 2018.

ISSN 2237-9126

\section{Introdução}

Este texto é parte das pesquisas, reflexões, questionamentos e problematizações que vêm sendo desenvolvidos, desde 2010, sobre a fotografia de arquitetura e cidade. Este esforço de pensar, questionar e buscar entender a fotografia de arquitetura e cidade resultaram um uma tese de doutorado, em 2012, intitulada "A fotografia na percepção da arquitetura" (VIEIRA, 2012) e em uma dezena de textos também disponíveis no LUME Repositório Digital - UFRGS (www.lume.ufrgs.br).

Em 2013, no IV ENEIMAGEM, foi apresentado um texto intitulado "Fotografia urbana de Cristiano Mascaro: a cidade reconfigurada" onde foram apresentadas e problematizadas as fotografias da cidade de São Paulo, feitas por Cristiano Mascaro, e apresentadas em sua tese de doutorado de 1994, em seu livro "A Cidade" e no seu site, na coleção sobre "São Paulo: a Cidade". Através da análise destas imagens fotográficas pretendeu-se propor reflexões sobre como se dá o registro da "realidade" procurando entender os padrões visuais estabelecidos e explorados pelo fotógrafo (VIEIRA, 2013).

Em 2015, no $\vee$ ENEIMAGEM, foi trazido o texto "Fotografia da cidade: realidade reconfigurada", onde se pretendeu problematizar a fotografia da cidade. Foi proposto, neste texto, reflexões sobre como se dá o registro da "realidade" - o possível distanciamento do referente (ou abstração) procurando entender as mudanças de visualidade por elas produzidas. Uma vez que estas fotografias apresentam um ambiente reconstruído pelo olho sensivel do fotógrafo e codificado pelo aparato técnico, plenamente explorado, podese esperar que sejam capazes de sugerir a seus leitores/receptores imagens de uma cidade diferente, reconfigurada (VIEIRA, 2015).

Agora, este texto, busca problematizar de que maneira o "jogo fotográfico", praticado entre operador, câmera, cenário e leitor pode alterar, permitir e, porque não especular, direcionar no sentido de uma construção de 
VIEIRA, César Bastos de Mattos. A arquitetura e a cidade no jogo fotográfico. Domínios da Imagem, Londrina, v. 12, n. 23, p. 32-50, jul./dez. 2018.

ISSN 2237-9126

um imaginário alterado da "realidade" de edificações e cidades, onde o que não é passível de ser fotografado não existe.

\section{Discussão teórica}

A arquitetura e a cidade sempre se prestaram de modelos fotográficos. Em parte, por serem estáticos, e também, por estarem à vista das janelas dos pioneiros que buscavam descobrir uma maneira de fixar a imagem formada dentro da câmera escura. Constata-se essas afirmações ao observar, que nos primeiros registros fotográficos, lá estão presentes objetos arquitetônicos e/ou parcelas de cidade. É assim, em um dos primeiros registros fotográficos fixados: a fotografia intitulada "Vista da janela de Le Grás" - vista que se tinha da janela do andar de cima da casa de campo da família de Joseph Nicéphore Niépce, feita em 1826'.

Esta imagem não apresenta riqueza de detalhes, entretanto dava indícios de que seria possível a fixação da imagem formada na câmera escura sem a intermediação da mão humana e sim, por intermédio de conhecimentos de química. O fato deste registro se dar de forma direta atribuiria à fotografia o seu caráter de precisão e honestidade.

A arquitetura e a cidade aparecem também nos experimentos de Luis Jaques Mandé Daguerre, como na "Vista do Boulevard du Temple", Paris. Um Daguerreótipo realizado em 1838 (NEWHALL, 1983. p.17)². É notória a melhora na qualidade da imagem e o consequente aumento na riqueza de detalhes.

Com Willian Henry Fox Talbot, também pode ser observado, nas primeiras imagens fotográficas, que aparecem cenas onde a arquitetura está

\footnotetext{
1 Esta fotografia pode ser vista no site da National Geographic. Disponível em: http://photography.nationalgeographic.com/photography/photos/milestonesphotography/. Acesso em 1 ago. 2017.

2 Pode ser vista, também, no site: https://en.wikipedia.org/wiki/File:Boulevard_du_Temple_by_Daguerre.jpg. Acesso em 1 ago. 2017.
} 
VIEIRA, César Bastos de Mattos. A arquitetura e a cidade no jogo fotográfico. Domínios da Imagem, Londrina, v. 12, n. 23, p. 32-50, jul./dez. 2018.

ISSN 2237-9126

presente. A primera fotografia de Talbot, de 1835, foi de uma janela (ROSENBLUM, 2007. p.28)3.

Assim, os elementos arquitetônicos seguem sendo alvos das lentes, como pode ser verificada na fotografia intitulada "The Open Door", de Willian Henry Fox Talbot, de 1843 (ROSENBLUM, 2007. p.28)4.

Percebe-se nessas fotografias pioneiras uma melhora gradativa na definição e na riqueza de detalhes. Há uma impressionante e indiscutível semelhança entre a cena, que serviu de modelo, e a imagem fotográfica fixada. Este "efeito de realidade percebido pelo olhar ingênuo" (DUBOIS, 2001. p.26) perpetua-se até os dias de hoje.

Algo de singular, que a diferencia dos outros modos de representação, subsiste apesar de tudo na imagem fotográfica: um sentimento de realidade incontestável do qual não conseguimos nos livrar apesar da consciência de todos os códigos que estão em jogo nela e que se combinaram para a sua elaboração. (DUBOIS, 2001. p.26)

Apesar de ser do senso comum que a fotografia é um registro fiel do seu referente "real", na prática fotográfica constata-se que esta crença de fidelidade não está plenamente presente em todos os registros fotográficos. Há uma combinação de códigos oriundos da óptica, da física, da química e da eletrônica que interferem na construção do registro fotográfico e que podem resultar em uma imagem diferente de seu referente "real". Esta percepção já era de conhecimento dos teóricos pioneiros, tais como Walter Benjamin, que afirmava: "a natureza que fala com a câmera é distinta da que fala ao olho" (2008. p.26 Tradução do pesquisador). Em 1975, Cervin Robinson (1975)5, também alertava para estas "discrepâncias entre a imagem e a

\footnotetext{
${ }^{3}$ Fotografia, também, disponível em: https://commons.wikimedia.org/wiki/File:Latticed_window_at_lacock_abbey_1835.jpg. Acesso em 1 ago. 2017.

${ }^{4}$ Fotografia, também, disponível em: http://www.metmuseum.org/art/collection/search/283068. Acesso em 1 ago. 2017.

5 Fotógrafo, historiador e crítico, Cervin Robinson é reconhecido como um dos mais destacados estudiosos da arquitetura americana. Robinson faz palestras e escreve regularmente para vários periódicos acadêmicos e de arquitetura e tem lecionado fotografia de arquitetura na Universidade de Columbia. Disponível em:
} 
VIEIRA, César Bastos de Mattos. A arquitetura e a cidade no jogo fotográfico. Domínios da Imagem, Londrina, v. 12, n. 23, p. 32-50, jul./dez. 2018.

ISSN 2237-9126

realidade", no Journal of Architectural Education (JAE). Já Arlindo Machado, no prefácio do livro de Flusser, Ensaios sobre a fotografia: para uma filosofia da técnica, também destaca a inexistência de uma equivalência direta e objetiva entre o registro fotográfico e seu referente "real", ao afirmar:

[...] a imagem fotográfica não tem nenhuma objetividade preliminar, não corresponde a qualquer duplicação automática do mundo; ela é constituída de signos abstratos forjados pelo aparato (câmera, objetiva, película), pois a sua função é materializar conceitos científicos. (MACHADO in: FLUSSER, 1998. p.13)

Na mesma linha, Giovanni Fanelli, em seu livro Histoire de la photographie d'architecture, vem ao encontro das hipóteses aqui defendidas ao afirmar:

\begin{abstract}
A imagem fotográfica não é a reprodução ou o simples registro da realidade. Ela constitui em uma outra realidade, dotada de características próprias, e influencia a própria ideia de realidade. Ele não é equivalente à percepção exata da realidade da arquitetura, espaço urbano ou paisagem. Aqui também, é uma realidade diferente. (2016. p. 1 Tradução do pesquisador)
\end{abstract}

Aqui Fanelli alerta para a possibilidade de interferência da fotografia na construção de um imaginário distorcido ou, pelo menos, com perdas de equivalência com seu referente "real", ao colocar em cheque a própria ideia de realidade.

\title{
A tese defendida
}

Perpetua-se, entretanto, na sociedade atual, uma crença na verossimilhança e honestidade da fotografia. Muito disso se dá por se estar inserido em uma sociedade onde há uma incontestável "hegemonia da visão" (PALLASMAA, 2011). Vive-se em uma sociedade onde se fotografa tudo

http://designobserver.com/author/cervin-robinson/1417/. Acesso em 1 out. 2011. 
VIEIRA, César Bastos de Mattos. A arquitetura e a cidade no jogo fotográfico. Domínios da Imagem, Londrina, v. 12, n. 23, p. 32-50, jul./dez. 2018.

ISSN 2237-9126

e todos. Aparentemente, para existir tem que ser passível de pelo menos um registro fotográfico impactante, espetacular. O que leva a crer que o que não é fotografável não existe.

É neste contexto de imersão e dominação de uma "visão fotográfica" que se propõe refletir sobre a real capacidade da fotografia de registrar tudo e todos de maneira tão precisa e, por isso, encontra-se uma certa resistência às provocações apresentadas. É necessário um certo distanciamento para que se possa observar e questionar valores e crenças tão fortemente arraigados.

Arlindo Machado, em seu livro A llusão especular: uma teoria da fotografia (2015) corrobora com o que é defendido nessa pesquisa alertando para diversas possibilidades de alteração no registro fotográfico, seus códigos e maneiras de registrar a cena visível com afirmações contundentes como esta:

A câmera fotográfica é, antes de tudo, um aparelho que visa produzir a perspectiva renascentista e não visa isto por acaso: toda nossa tradição cultural logrou identificar essa construção perspectiva com o efeito de "real" e por isso a fotografia faz basear o seu ilusionismo homológico na ideologia que está cristalizada nesta técnica. (MACHADO, 2015. p.76)

Defende-se a tese de que a fotografia, na verdade, não é capaz de registrar com a mesma precisão e verossimilhança todo o universo visível. Sendo isto verdade, haveria, então, uma parcela de "realidade" que estaria sendo desconsiderada ou pelo menos negligenciada. Posta a margem das construções imagéticas de mundo. Este fato poderia estar tendo consequências significativas na representação, apresentação e apreensão da arquitetura e da cidade.

Boris Kossoy alerta para a existência de um receptor desavisado e a consequente possibilidade de uma construção imagética deformada da realidade ao afirmar: 
VIEIRA, César Bastos de Mattos. A arquitetura e a cidade no jogo fotográfico. Domínios da Imagem, Londrina, v. 12, n. 23, p. 32-50, jul./dez. 2018.

ISSN 2237-9126

Uma imagem que se apoia no realismo fotográfico (da aparência) enquanto testemunho fiel, enquanto "prova" que pode conduzir o receptor desavisado a imaginar uma situação verdadeira que não existe, para criar, enfim, no imaginário dos receptores uma (pseudo) realidade. (KOSSOY, 2009. p.127)

Não se pode negar que a fotografia "é literalmente uma emanação do referente" (BARTHES, 2008. p.91), entretanto ela é codificada pelas leis da óptica, da física, da química e, mais contemporâneamente, da eletrônica. Essa codificação tem, como consequência direta, a criação de imagens que vão apresentar um certo grau de discrepância com o seu referente e, como se observa na prática fotográfica, às vezes até um certo desaparecimento desse referente. São diversos os fatores de codificação. Um dos mais óbvios é descrito por Flusser:

Imagens são superfícies que pretendem representar algo. Na maioria dos casos, algo que se encontra lá fora no espaço e no tempo. As imagens são, portanto, resultado do esforço de se abstrair duas das quatro dimensões no plano. (FLUSSER, 2002, p. 7)

Flusser, neste texto, traz à tona uma das possibilidades de uso da fotografia, que é a de representação de algo. Neste sentido a fotografia assumiu, no campo da arquitetura e da cidade, um papel fundamental e atualmente imprescindível. Nos dias atuais, os principais meios de representação e apresentação em arquitetura e urbanismo são as "vistas" desenhos baseados em vistas ortogonais -, as perspectivas renascentistas e a fotografia - seja a real (utilizando-se equipamentos fotográficos para registro do existente) ou seja a virtual (utilizando-se a câmera fotográfica disponível nos programas de CAD). É possível constatar, então, a importância do "olho monocular", do "olhar do Cíclope" nos principais meios de representação. Percebe-se, assim, como a visão dominou e continua dominando os meios de representação em arquitetura e urbanismo.

Dentro deste contexto, a fotografia tornou-se uma das ferramentas mais importantes e potentes no registro, representação, apresentação e 
VIEIRA, César Bastos de Mattos. A arquitetura e a cidade no jogo fotográfico. Domínios da Imagem, Londrina, v. 12, n. 23, p. 32-50, jul./dez. 2018.

ISSN 2237-9126

apreensão em arquitetura e urbanismo. Entretanto, não parece existir uma crítica, um cuidado na utilização desta ferramenta. Como já foi dito acima, há discrepâncias entre o "real" e o registro fotográfico. Haveria, assim, uma parcela da arquitetura e da cidade que não se deixam fotografar satisfatoriamente. É no sentido de alertar e refletir sobre este fenômeno que se concentram os esforços desta pesquisa e deste texto.

Pode-se entender a fotografia como um jogo com vários atores envolvidos e cada um deles contribuindo, de alguma forma, para que o registro seja capaz de capturar, ou não, informações da cena "real" e, depois, consiga comunicar essas informações para o receptor/leitor. Desta forma, podem ser considerados atores deste jogo: o aparato tecnológico (a câmera, suas lentes, filmes, sensores, papeis fotográficos, etc.), o fotógrafo/operador, a cena a ser registrada e, por fim, o leitor/receptor. Entender um pouco sobre a maneira de como se desenrola esse jogo pode auxiliar a entender melhor 0 processo de registro e leitura da "realidade" e da consequente construção da imagem mental.

O aparato tecnológico - a câmera - é regido por leis da física e da óptica e possui demandas específicas que determinam o grau de sucesso do registro fotográfico. Propõe-se, neste texto, começar as reflexões por estas demandas fundamentais.

\section{As demandas fundamentais da fotografia}

Já na tese de doutorado, defendida em 2012, Vieira apresenta diversos aspectos e peculiaridades que podem distanciar o registro fotográfico de seu referente real e que abrangem desde aspectos ligados ao aparato tecnológico até as responsabilidades do operador e do leitor. Entre as reflexões propostas na tese, acredita-se importante salientar, neste trabalho, "as demandas fundamentais da fotografia", tratadas no capítulo 3.3 (VIEIRA, 2012. p.105-110). Trata-se de entender as exigências necessárias para que o 
VIEIRA, César Bastos de Mattos. A arquitetura e a cidade no jogo fotográfico. Domínios da Imagem, Londrina, v. 12, n. 23, p. 32-50, jul./dez. 2018.

ISSN 2237-9126

registro fotográfico consiga apreender de maneira minimamente satisfatória a cena visível que se pretende registrar. Estas demandas fundamentais são: distância, luz e ordenamento.

A distância é a primeira demanda fundamental para que se possa lograr um registro fotográfico satisfatório. Em 1820, Nicéfore Niepce definia sua invenção como: "O ponto de vista é um conjunto de objetos sobre os quais a visão se volta e se paralisa em um certo distanciamento"(in: VIRILIO, 2002. p.38) ${ }^{6}$. Esse distanciamento é necessário para que se consiga enquadrar o modelo dentro de campo visual oferecido pela câmera e sua lente. Atualmente há a possibilidade de utilização de lentes super grande angulares que reduzem a necessidade de grandes distanciamento, entretanto, o uso destas objetivas resultam em aberrações dimensionais significativas, também apresentadas por Vieira em sua tese. Esse distanciamento, para o caso da arquitetura e da cidade, não é sempre possível. Os espaços arquitetônicos, a malha urbana, a dimensão das ruas ou os afastamentos entre os entes arquitetônicos não foram, necessariamente, planejados e pensados para possibilitar tomadas fotográficas. Seria uma explicação do porquê as fotografias de cidade, por exemplo, são geralmente tomadas de praças, esquinas e largos. Ficam, desta maneira, de fora do registro fotográfico das cidades os miolos de quadra, as ruas estreitas, os becos etc.

Já a demanda por luz é de fácil entendimento e consenso. Uma vez que a fotografia é "uma escrita com luz", a falta, o exagero e a qualidade da luz vão determinar de maneira significante a qualidade do registro fotográfico. Todavia, não parece que se tenha noção clara da dimensão das limitações que a luz impõe ao registro fotográfico. Por exemplo: locais com grande variação de luz possibilitarão registros fotográficos limitados. Em uma situação dessas, apenas uma das qualidades de luz será bem registrada, ou seja, se o fotógrafo eleger registrar as luzes médias, no registro fotográfico, se perderá informações no que está em altas luzes e em baixas luzes.

${ }^{6}$ Correspondência entre Nicéfore e Claude Niepce. 
VIEIRA, César Bastos de Mattos. A arquitetura e a cidade no jogo fotográfico. Domínios da Imagem, Londrina, v. 12, n. 23, p. 32-50, jul./dez. 2018.

A figura 01 ilustra o que ocorre quando se tenta fazer um registro em uma rua estreita com uma condição de luz extrema. Esta fotografia foi feita no casco medieval da cidade de Barcelona, Espanha, e apresenta perdas significativas de informação nas áreas de baixas luzes além de apresentar uma restrição significativa na visualização dos prédios devido à pouca largura da rua.

Figura 1 - Casco medieval da cidade de Barcelona, Espanha.

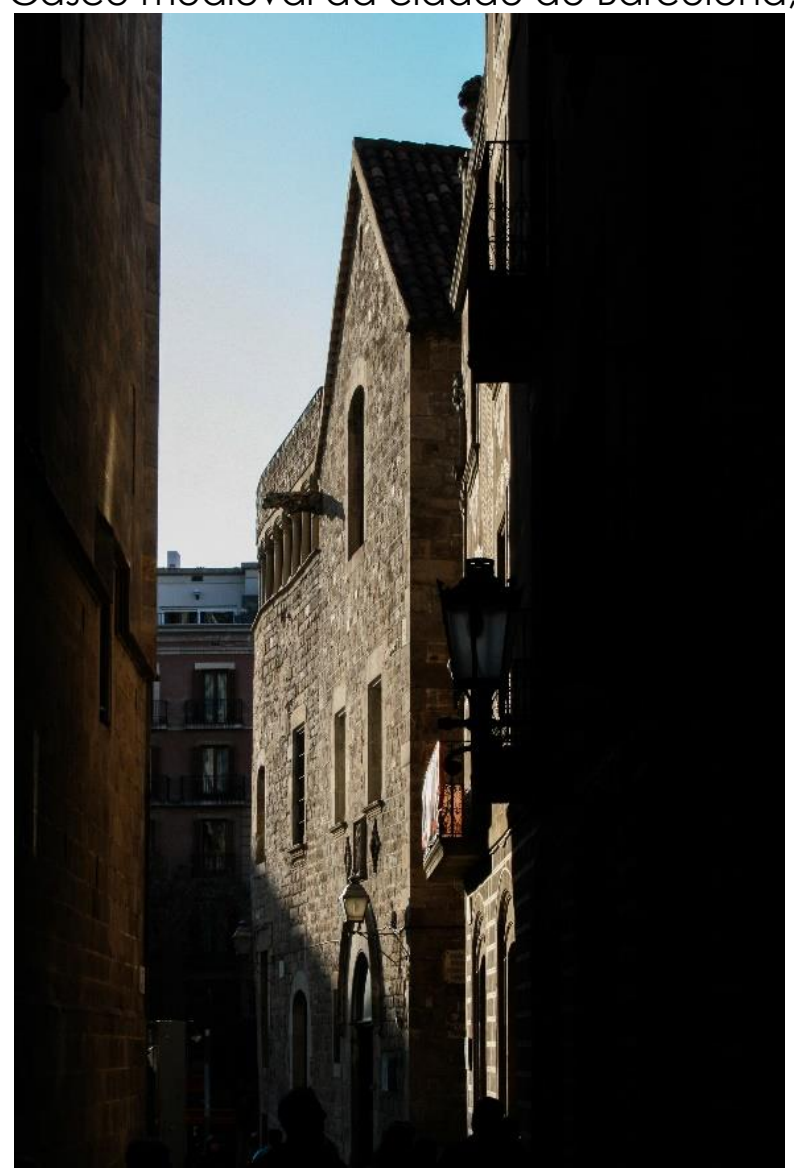

Fonte: César Vieira.

Já o ordenamento da cena é, novamente, um ponto pouco estudado e problematizado, mas fundamental para que o registro fotográfico seja rico de informações.

Ali onde o desfocado, o confuso, o sinuoso, o escurecido, o irregular reina, a objetiva não pode ver, impor suas regras, traduzir em nitidez, precisão, regularidade e iluminação. (FUÃO, 1992. p. 50 - tradução do pesquisador) 
VIEIRA, César Bastos de Mattos. A arquitetura e a cidade no jogo fotográfico. Domínios da Imagem, Londrina, v. 12, n. 23, p. 32-50, jul./dez. 2018.

ISSN 2237-9126

Com esta afirmação, Fuão corrobora com a tese defendida por Vieira e coloca em cheque a capacidade, entendida pelo senso comum, de que a fotografia é capaz de registrar com eficiência todo o universo visível. Pode-se afirmar, então, que há uma parcela do universo circundante que não é passível de um registro fotográfico satisfatório, que não se mostra pela fotografia e que, portanto, ficaria de fora da representação de mundo de uma sociedade baseada na imagem fotográfica e no espetáculo visual.

A figura 02 apresenta uma tomada do Parque das Nações, em Lisboa, Portugal. Nesta fotografia estão presentes vários prédios de arquitetura representativa da nova arquitetura portuguesa, entretanto, o ponto da visada e a maneira como os prédios estão dispostos resultou em uma confusão visual tão grande que desmerece todo o conjunto urbano.

Figura 2 - Parque das Nações, Lisboa, Portugal.

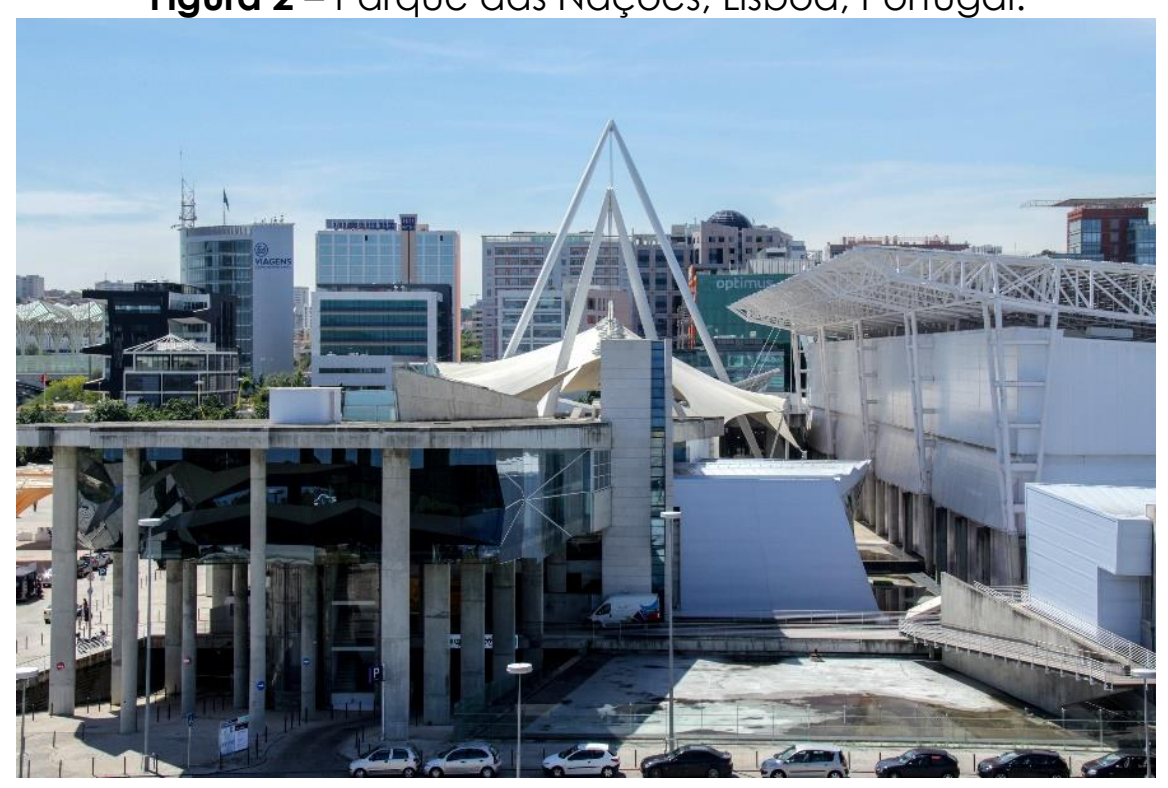

Fonte: César Vieira.

Uma fotografia dessas pode tirar de cena um lugar importante apenas porque não "ter saído bem na foto". São nestes termos que se concentram as preocupações desta pesquisa. Como Peter Burke afirma: "Para utilizar a evidência de imagens de forma segura, e de modo eficaz, é necessário, como 
VIEIRA, César Bastos de Mattos. A arquitetura e a cidade no jogo fotográfico. Domínios da Imagem, Londrina, v. 12, n. 23, p. 32-50, jul./dez. 2018.

ISSN 2237-9126

no caso de outros tipos de fonte, estar consciente de suas fragilidades" (BURKE, 2004. p.18).

\section{O fotografável e o não fotografável}

Este conceito foi tratado por Vieira, na sua tese, de 2012, no capítulo 4.3 - A fotogenia na arquitetura.

Fotogênico é um adjetivo que pode significar: "que produz imagens pela ação da luz" ou "que se representa bem pela fotografia: sem ser bonita, é notavelmente fotogênica" (Dicionário Aurélio Digital). Este não é um fenômeno relativo ao aparato técnico (a câmera fotográfica), nem ao seu operador (fotógrafo) nem ao leitor. Este é um fenômeno referente ao 'modelo', ao que é fotografado. Como ele 'se oferece' para a objetiva e como satisfaz as demandas e leis da fotografia. (VIEIRA, 2012. p.290)

Já Sontag pondera: "Mas poucos têm a sorte de ser fotogênicos - ou seja, parecer melhor nas fotos do que na vida real" (SONTAG, 2004. p.102). Esta característica, de alguns modelos, é situação corriqueira na fotografia de arquitetura e cidade. Sendo assim, propõe-se refletir sobre as consequências deste fenômeno na construção de uma imagem da cidade, por exemplo. Não estaria sendo privilegiado certos entes arquitetônicos e certas parcelas da cidade apenas por serem mais fotogênicos do que outros? O que não é fotogênico não estaria sendo fotografado e, por conseguinte, estaria ficando de fora. Se forem consideradas as dificuldades de se fazer um registro satisfatório, ou seja, que se tornam "não fotografável" tudo aquilo que não satisfizer as demandas fundamentais da fotografia, uma parcela considerável da cidade e de entes arquitetônicos, estariam ficando de fora dos inventários e da construção imagética da arquitetura e da cidade, por quem não tem um contato direto com elas. Fato cada vez mais comum e frequente. 
VIEIRA, César Bastos de Mattos. A arquitetura e a cidade no jogo fotográfico. Domínios da Imagem, Londrina, v. 12, n. 23, p. 32-50, jul./dez. 2018. 
VIEIRA, César Bastos de Mattos. A arquitetura e a cidade no jogo fotográfico. Domínios da Imagem, Londrina, v. 12, n. 23, p. 32-50, jul./dez. 2018.

ISSN 2237-9126

\section{Os programas do aparato fotográfico}

Outra maneira de abordar este tema é pensar o jogo fotográfico a partir da proposta de Flusser em seu livro Filosofia da caixa preta: ensaios para uma futura filosofia da fotografia. Para Flusser há programas inseridos dentro do aparato tecnológico e fala do papel do fotógrafo de explorá-los:

O fotógrafo manipula o aparelho, apalpa-o, olha para dentro e através dele, a fim de descobrir sempre novas potencialidades. Seu interesse está concentrado no aparelho e o mundo lá fora só interessa em função do programa. Não está empenhado em modificar o mundo, mas em obrigar o aparelho a revelar suas potencialidades. (FLUSSER, 2002. p.23)

Vendo a fotografia do ponto de vista de Flusser, exige do leitor/pesquisador buscar entender as peculiaridades do aparelho fabricado por uma indústria e programado para produzir imagens:

Hardware e software. Enquanto objeto duro, o aparelho fotográfico foi programado para produzir automaticamente fotografias; enquanto coisa mole, implacável, foi programado para permitir ao fotógrafo fazer com que fotografias deliberadas sejam produzidas automaticamente. [...] são as virtualidades contidas nas regras: o software. [...] É o aspecto mole, implacável e simbólico, o verdadeiro portador de valor no mundo pós-industrial dos aparelhos. Transvalorização de valores; não é o objeto, mas o símbolo que vale. (FLUSSER, 2002. p. 26 e 27$)$

Sob essa ótica, pode-se entender a sociedade atual apenas verificando as alterações e incrementos nos programas inseridos no aparelho. Nas câmeras mais antigas tinha-se à disposição apenas quatro configurações básicas, a saber: retrato, macro, esporte e paisagem. (Figura 03) 
VIEIRA, César Bastos de Mattos. A arquitetura e a cidade no jogo fotográfico. Domínios da Imagem, Londrina, v. 12, n. 23, p. 32-50, jul./dez. 2018.

Figura 3 - Modos de cena disponíveis nas câmeras mais antigas.
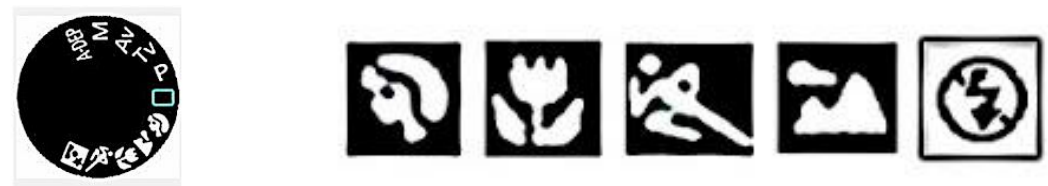

Fonte: Manual da Câmera Canon EOS 6D.

Com a sociedade tornando-se imagética e buscando o espetacular, as câmeras ampliaram seus programas para dar conta destas novas demandas. A figura 04 ilustra esta ampliação no programa. Pode-se perceber como a sociedade atual dá importância para festas, para viagens, pets e situações mais críticas de luz, como fotos noturnas, fogos de artifícios etc. De certa maneira, a espetacularização imagética é comtemplada por estes novos programas:

Figura 4 - Modos de cena disponíveis nas câmeras atuais.

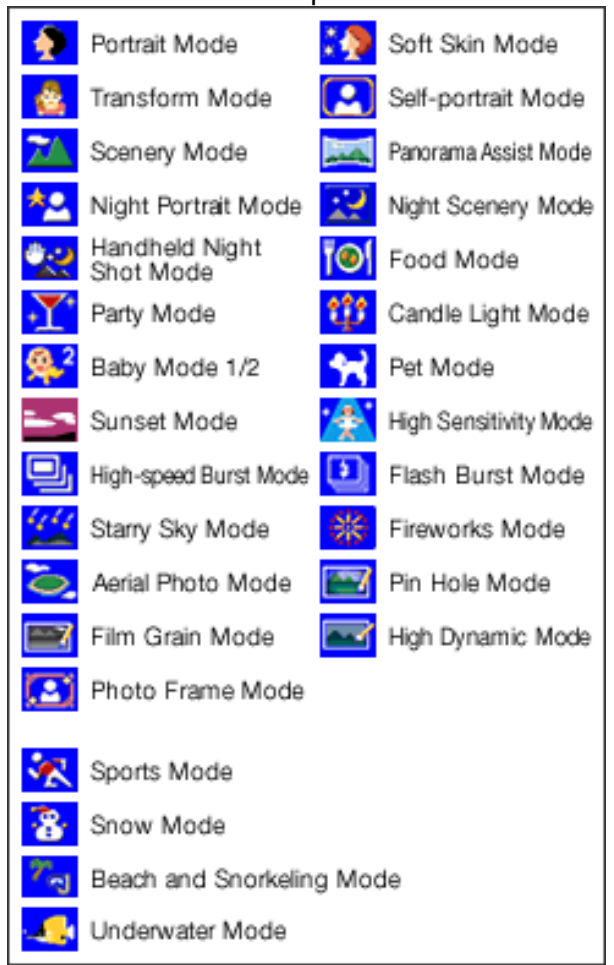

Fonte: http://www.panasonic.com.br/avc/lumix/compact/ts3 ft3/3d.html. Acesso em 30 jan. 2012. 
VIEIRA, César Bastos de Mattos. A arquitetura e a cidade no jogo fotográfico. Domínios da Imagem, Londrina, v. 12, n. 23, p. 32-50, jul./dez. 2018.

ISSN 2237-9126

Como sugeria Flusser, "a análise do gesto de fotografar, este movimento complexo aparelho-fotógrafo, pode ser um exercício para a análise da existência humana em situação pós-industrial, aparelhada" (2002. p.28).

\section{O fotógrafo/operador}

Outra abordagem possível do jogo fotográfico, é observá-lo a partir do seu operador: o fotógrafo. E, nesse caso, é importante ter em conta uma certa falta de consciência desse personagem do jogo onde é parte indispensável. Flusser é contundente, nesse ponto, ao afirmar:

Os fotógrafos são inconscientes da sua práxis. A revolução pósindustrial, tal como se manifesta pela primeira vez no aparelho fotográfico, passou despercebida pelos fotógrafos e pela maioria dos críticos de fotografia. (FLUSSER, 2002. p.75)

O fotógrafo joga o jogo sem ter consciência de todas as suas responsabilidades e possibilidades, conforme afirma Sontag:

[...] as fotos [...] devem a sua existência a uma vaga cooperação (quase mágica, quase acidental) entre o fotógrafo e o tema - mediada por uma máquina cada vez mais simples e mais automática, que é infatigável e que, mesmo quando se mostra caprichosa, pode produzir um resultado interessante e nunca inteiramente errado. (SONTAG, 2004. p.67)

Entretanto, o fotografo/operador tem um poder incrível no jogo fotográfico. É dele a responsabilidade das decisões do que entra ou fica fora de quadro, do disparo da câmera no momento decisivo, enfim, é ele que com sua bagagem cultural e suas intencionalidades vai construir a imagem fotográfica. Conforme Fanelli, "o poder do fotógrafo para melhorar ou destruir o original é inegável". (2016. p.1) 
VIEIRA, César Bastos de Mattos. A arquitetura e a cidade no jogo fotográfico. Domínios da Imagem, Londrina, v. 12, n. 23, p. 32-50, jul./dez. 2018.

ISSN 2237-9126

\section{O leitor}

O leitor, é um ator do jogo fotográfico essencial, pois é dele o papel de reconstrução da realidade registrada. Para saber ler plenamente uma fotografia, desconfiar das informações apresentadas é uma atitude fundamental. A fotografia parece possibilitar uma leitura direta, mas esta é uma armadilha perigosa. Flusser já avisava:

De modo geral, todo mundo possui um aparelho fotográfico e fotografa, assim como, praticamente, todo mundo está alfabetizado e produz textos. Quem sabe escrever, sabe ler; logo, quem sabe fotografar sabe decifrar fotografias. Engano. (FLUSSER, 2002. p.53)

E complementa:

Fotografias são imagens técnicas que transcodificam conceitos em superfícies. Decifrá-las é descobrir o que os conceitos significam. Isto é complicado, porque na fotografia se amalgamam duas intenções codificadoras: a do fotógrafo e a do aparelho. O fotógrafo visa a eternizar-se nos outros por intermédio da fotografia. O aparelho visa a programar a sociedade através das fotografias para um comportamento que the permita aperfeiçoar-se. A fotografia é, pois, mensagem que articula ambas as intenções codificadoras. Enquanto não existir crítica fotográfica que revele esta ambiguidade do código fotográfico, a intenção do aparelho prevalecerá sobre a intenção humana. (FLUSSER, 2002. p.43)

Conforme Joly (2008. p.44), "é preciso não esquecer, com efeito, que se toda a imagem é representação, tal implica que ela utilize necessariamente regras de construção". Sendo assim, conhecer essas regras de construção é fundamental para que seja possível a decifração minuciosa e completa da imagem fotográfica. 
VIEIRA, César Bastos de Mattos. A arquitetura e a cidade no jogo fotográfico. Domínios da Imagem, Londrina, v. 12, n. 23, p. 32-50, jul./dez. 2018.

ISSN 2237-9126

\section{Considerações finais: As consequências do desconhecimento do "jogo fotográfico"}

A valorização excessiva da imagem fotográfica sobre a própria realidade, característica de uma sociedade fotográfica e espetacular, poderiam estar interferindo de maneira perigosa na construção imagética com especial interesse na área de arquitetura e cidade. Fuão já alertava, em 1994, para a diferença significativa entre a experimentação direta e a apresentação, apreensão intermediada por imagens tão valorizada na sociedade atual.

O ritmo lento e complexo do caminhar, ver, tocar, sentir os cheiros característicos que banham as cidades, os espaços, é substituído por uma onividência artificial criada pelos meios de comunicação. Os arquitetos, cada vez mais insaciáveis de imagens, partem destas para projetar, produzir suas arquiteturas. Já não se inspiram, se (ex)piram de imagens. (FŨ̃O, 1994. p.84)

Flusser, por sua vez, vê no aparelho fotográfico a fonte de toda essa alteração na maneira de perceber o mundo.

A robotização dos gestos humanos já é facilmente constatável. (...) Menos facilmente, mas ainda possível, é ela constatável nos produtos intelectuais da atualidade. Nos textos científicos, poéticos, nas composições musicais, na arquitetura. Tudo vai se robotizando, isto é, obedece a um ritmo staccato. A crítica da cultura começa a descobri-lo. Sua tarefa seria a de indagar até que ponto o universo da fotografia é responsável pelo que está acontecendo. A hipótese aqui defendida é esta: a invenção do aparelho fotográfico é o ponto de partida do qual a existência humana vai abandonar a estrutura de deslizamento linear, próprio dos textos, para assumir a estrutura de saltear quântico, próprio dos aparelhos. [...] Portanto, o aparelho fotográfico é a fonte da robotização da vida em todos os seus aspectos, desde os gestos exteriorizados ao mais íntimo dos pensamentos, desejos e sentimentos. (FLUSSER, 2002. p.67 Grifo do pesquisador)

Ao aceitar e entrar no jogo fotográfico toda a sociedade foi, de certa maneira, abduzida por um pensar fotograficamente. A forma de perceber $\mathrm{O}$ 
VIEIRA, César Bastos de Mattos. A arquitetura e a cidade no jogo fotográfico. Domínios da Imagem, Londrina, v. 12, n. 23, p. 32-50, jul./dez. 2018.

ISSN 2237-9126

mundo passou a ser sinônimo de "ver", mas de "ver fotograficamente". Assim, quando a "realidade" ficou de fora do registro fotográfico quem dominou o jogo foi o aparelho. É necessária uma tomada de consciência por parte dos demais jogadores - operadores e leitores - de seus papeis, funções e potencialidades para que esse jogo reestabeleça um equilíbrio e que seus atores sejam conscientes de seus fazeres e responsabilidades.

Reconhecer que a fotografia não é capaz de registrar o universo visível na sua totalidade é o primeiro passo para se poder pensar em alternativas que incluam essa parcela de "realidade" que fica de fora do registro fotográfico. Fica evidente a necessidade de inclusão de ferramentas de representação complementares ao inventário fotográfico de arquitetura e cidade, para que se consiga abarcar uma parcela maior de "realidade" obtendo-se, assim, uma representação mais abrangente.

Tirar da fotografia seu status hegemônico poderia permitir uma reflexão mais ampla sobre as possibilidades de representação de mundo e em especial da arquitetura e da cidade. Esse repensar nas maneiras de representação podem trazer de volta a parcela de realidade deixada de lado pela fotografia.

\section{Referências}

BARTHES, Roland. A câmera clara: notas sobre a fotografia. Lisboa, Portugal: Edições 70, 2008.

BENJAMIN, Walter. Sobre La fotografia. Pré-textos. 4 ed. Trad. José Muñoz Millanes, Valencia, Espanha: Imprenta Kadmos, 2008.

BURKE, Peter. Testemunha ocular: história e imagem. Trad. Vera Maria Xavier dos Santos. Bauru, SP: EDUSC, 2004.

DUBOIS, Philippe. $O$ ato fotográfico e outros ensaios. 5 ed. Campinas: Papirus, 2001.

FANELLI, Giovani. Historie de la photographie d'architecture. Edição francesa revisada e aumentada com a colaboração de Barbara Mazza. Lausanne: Presses polytechniques et universitaires romandes, 2016. 
VIEIRA, César Bastos de Mattos. A arquitetura e a cidade no jogo fotográfico. Domínios da Imagem, Londrina, v. 12, n. 23, p. 32-50, jul./dez. 2018.

FLUSSER, Vilém. Ensaios sobre a fotografia: para uma filosofia da técnica. Lisboa: Relógio D'água Editores, 1998.

Filosofia da caixa preta: ensaios para uma futura filosofia da fotografia. Rio de Janeiro: Relume Dumará, 2002.

FUÃO, Fernando Delfino de Freitas. Arquitectura como collage. Tese (Doutorado em Arquitetura) - Escola Técnica Superior d'Arquitectura de Barcelona, Universidad Politécnica de Catalunya, Barcelona, 1992.

Papel do papel: as falhas da arquitetura e a arquitetura mesma.

Revista Projeto, jun. 1994.

JOLY, Martine. Introdução à análise da imagem. Lisboa, Portugal: Edições 70, 2008.

KOSSOY, Boris. Realidades e ficções na trama fotográfica. 4 ed. São Paulo: Ateliê Editorial, 2009.

MACHADO, Arlindo. A ilusão especular: uma teoria da fotografia. São Paulo: Gustavo Gili, 2015.

NEWHALL, Beaumont. Historia de la fotografia. Barcelona: Editorial Gustavo Gili, 1983.

PALLASMAA, Juhani. Os olhos da pele: a arquitetura e os sentidos. Porto Alegre: Bookman, 2011.

ROBINSON, Cervin. Architectural photography. Journal of Architectural Education (JAE), v. 29, n. 2, p. 10-15, nov. 1975. Publicado por Blakwell Publishing em nome de ACSA - Association of Collegiate Schools of Architecture, Inc.

p. 10.

Disponível em:

http://www.jstor.org/stable/1424476. Acesso em 15 set. 2011.

ROSENBLUM, Naomi. A world history of photography. 4 ed. New York: Abbevile Press Publishers, 2007.

SONTAG, Susan. Sobre fotografia. 3 ed. São Paulo: Companhia da Letras, 2004.

VIEIRA, César Bastos de Mattos. A fotografia na percepção da arquitetura. Tese (Doutorado em Arquitetura) - Universidade Federal do Rio Grande do Sul, Porto Alegre. 2012. 

Imagem, Londrina, v. 12, n. 23, p. 32-50, jul./dez. 2018.

Fotografia urbana de Cristiano Mascaro: a cidade reconfigurada. In: Anais do $4^{\circ}$ Encontro Nacional de Pesquisadores da Imagem. Londrina : UEL, 2013. p. 703-719.

Fotografia da cidade: realidade reconfigurada. In: Anais do $5^{\circ}$ Encontro Nacional de Estudos da Imagem. Londrina: UEL, 2015. p. 296-316.

VIRILIO, Paul. A máquina de visão. 2. ed. Trad. Paulo Roberto Pires. Rio de Janeiro: José Olympio, 2002. 